\title{
PENGARUH PERUBAHAN NILAI PARAMETER TERHADAP NILAI ERROR PADA METODE RUNGE-KUTTA ORDE 3
}

\author{
Tornados P. Silaban ${ }^{1}$, Faiz Ahyaningsih ${ }^{2}$ \\ ${ }^{1)}$ FMIPA, UNIMED, Medan, Indonesia \\ email: tornados.p_silaban@yahoo.com \\ ${ }^{2)}$ Dosen Matematika FMIPA, UNIMED, Medan, Indonesia
}

\begin{abstract}
ABSTRAK
Metode Runge-Kutta merupakan suatu metode numerik yang digunakan untuk mencari solusi dari suatu persamaan. Metode ini berusaha mendapatkan derajat ketelitian yang lebih tinggi, dan sekaligus menghindarkan keperluan mencari turunan yang lebih tinggi dengan jalan mengevaluasi fungsi $f(x, y)$ pada titik terpilih dalam setiap selang langkah. Dalam tulisan ini dibahas tentang pengaruh perubahan nilai parameter $(h)$ terhadap nilai error pada metode Runge-Kutta Ordo-3. Persamaan yang akan dibahas yaitu persamaan diferensial biasa linier tingkat dua yang telah di ubah kedalam sistem persamaan linier. Dalam proses penelitian tidak ditemukan nilai parameter yang tetap untuk mendapatkan nilai error yang paling minimum, karena setiap parameter memiliki nilai error yang bervariasi pada masing-masing persamaan.
\end{abstract}

Kata Kunci: Runge-Kutta, parameter, error.

\begin{abstract}
Runge-Kutta method is a numerical method used to find the solution of an equation. This method seeks to obtain a higher degree of precision, and at the same time seeking to avoid the need of higher derivatives by evaluating the function $f(x, y)$ at the selected point in each interval step. In this paper discussed the effect of changes in the value of the parameter (h) to the value of the error in the Runge-Kutta method Order-3. The equation to be discussed is a linear ordinary differential equation of the two levels that have been changed into a system of linear equations. In the research process was not found fixed parameter values to get the minimum error value, because each parameter has a value of error varied for each equation.
\end{abstract}

Keywords: Runge-Kutta, parameters, error. 


\section{Pendahuluan}

Persamaan diferensial adalah suatu persamaan diantara derivatif-derivatif yang dispesifikasikan pada suatu fungsi yang tidak diketahui nilainya dan diketahui jumlah serta fungsinya [1]. .Persamaan diferensial biasa (PDB) adalah suatu persamaan diferensial yang terdiri dari satu variable bebas saja [2].

Persamaan diferensial berperan penting dalam kehidupan, sebab banyak permasalahan pada dunia nyata dapat dimodelkan dengan bentuk persamaan diferensial. Ada dua jenis persamaan diferensial yang kita kenal, yaitu persamaan diferensial biasa dan persamaan diferensial parsial. Yang akan dibahas dalam tulisan ini adalah persamaan diferensial biasa. Solusi dari persamaan diferensial adalah fungsi spesifik yang memenuhi persamaan. Persamaan dibawah ini merupakan contoh dari persamaan diferensial biasa yang memiliki solusi. Pada persamaan dibawah ini, $x$ merupkan variabel bebas dan $y$ merupakan variabel terikat. $y$ merupakan nama unknown function dari variabel $x$.

Penyelesaian suatu model matematika secara numerik memberikan hasil aproksimasi atau pendekatan yang berbeda dengan penyelesaian secara analitis. Adanya perbedaan inilah yang sering disebut sebagai error (kesalahan) [3]. Hubungan antara nilai eksak, nilai perkiraan dan error dapat dirumuskan sebagai berikut :

\section{Nilai eksak $=$ aproksimasi + error}

Dengan menyusun kembali persamaan di atas, diperoleh definisi dari kesalahan absolut (absolute error), yaitu:

\section{Kesalahan absolut $=$ nilaieksak - aproksimasi}

Metode Runge-Kutta memperoleh akurasi dari pendekatan deret Taylor tanpa memerlukan perhitungan derivatif yang lebih tinggi. Metode Runge-Kutta dikembangkan oleh dua ahli matematika Jerman. Mereka adalah Runge dan Kutta. Metode ini juga dibedakan dengan ordo-ordonya [4][5][7].

Banyak variasi dari metode Runge-Kutta, namun secara umum bentuknya adalah: 


$$
y_{i+1}=y_{i}+h \sum_{j-1}^{n} a_{j} k_{j}
$$

Dengan $a_{1}, a_{2}, a_{3}, \cdots, a_{n}$ adalah konstanta dan kadalah :

$$
\begin{gathered}
k_{j}=f\left(x_{i}+h p_{j}, y_{i}+h \sum_{l=1}^{j-1} q_{j l} k_{l}\right) \\
p_{1}=0
\end{gathered}
$$

Dimana diperoleh

$$
\begin{gathered}
k_{1}=f\left(x_{i}, y_{i}\right) \\
k_{2}=f\left(x_{1}+p_{2} h, y_{i}+q_{21} k_{1} \cdot h\right) \\
k_{3}=f\left(x_{1}+p_{3} h, y_{i}+q_{31} k_{1}+q_{32} k_{2} \cdot h\right) \\
\vdots \\
k_{n}=f\left(x_{1}+p_{n} h, y_{i}+q_{n 1} k_{1}+q_{n 2} k_{2}+\cdots+q_{n(n-1)} k_{(n-1)} \cdot h\right)
\end{gathered}
$$

$a, q$ dan pmerupakan parameter-parameter yang terdapat pada metode RungeKutta. Nilai parameter $a$ dipilih sedemikian rupa sehingga meminimumkan error per langkah, dan persamaan metode Runge-Kutta akan sama dengan metode deret Taylor dari ordo setinggi mungkin. Perhatikan bahwa $k$ adalah hubungan yangselalu berulang, $k_{1}$ hadir dalam persamaan untuk $k_{2}, k_{2}$ hadir dalam persamaan $k_{3}$,dan seterusnya..

Pada metode numerik ordo-2 terdapat empat parameter yang memiliki keterkaitan dimana dalam hal ini membuat metode Runge-Kutta tidak memiliki solusi yang unik. Solusi metode Runge-Kutta bergantung pada pemilihan nilai parameter yang diberikan. Pemilihan nilai parameter juga mempengaruhi besar-kecilnya nilai error [6].

Permasalahan yang dibahas adalah: 
1. Bagaimana solusi persamaan diferensial biasa secara analitik dan numerik yaitu menggunakan metode Runge-Kutta Ordo-3.

2. Bagaimana nilai kesalahan metode Runge-Kutta Ordo-3 terhadap perubahan nilai parameter yang diberikan.

3. Bagaimana pengaruh perubahan nilai salah satu parameter secara increament terhadap nilai kesalahan yang diperoleh.

\section{Metode Penelitian}

Adapun langkah-langkah yang dilakukan untuk mencapai tujuan penelitian ini adalah:

1. Menjelaskan tentang persamaan diferensial.

2. Menjelaskan tentang jenis-jenis persamaan diferensial.

3. Memilih salah satu persamaan diferensial yang digunakan, dimana dalam penelitian ini penulis memilih persamaan diferensial linear tingkat dua.

$$
\frac{d^{2} y}{d x^{2}}+P(x) \frac{d y}{d x}+Q(x) y=H(x)
$$

4. Menjelaskan tentang masalah nilai awal (Initial Value Problem).

5. Menjelaskan tentang pengertian nilai error dan pembagiannya. Hubungan antara nilai eksak, nilai perkiraan dan error dapat dirumuskan sebaga iberikut:

$$
\text { Nilai eksak }=\text { aproksimasi }+ \text { error }
$$

Dengan menyusun kembali persamaan di atas, diperoleh defines idari kesalahan absolut (absolute error), yaitu :

\section{Kesalahan absolut $=$ nilai eksak - aproksimasi}

Hubungan antara nilai eksak, nilai pendekatan dan error dapat dirumuskan sebagai berikut:

\section{Nilai eksak $=$ Pendekatan + error}

Error absolut suatu bilangan adalah selisih antara nilai sebenarnya dengan nilai pendekatan. Secara matematis, jika $y$ adalah solusi hampiran dan $y_{a}$ adalah solusi eksak, error dinyatakan oleh

$$
\varepsilon=y_{a}-y
$$

error dapat bernilai positif atau negatif. 


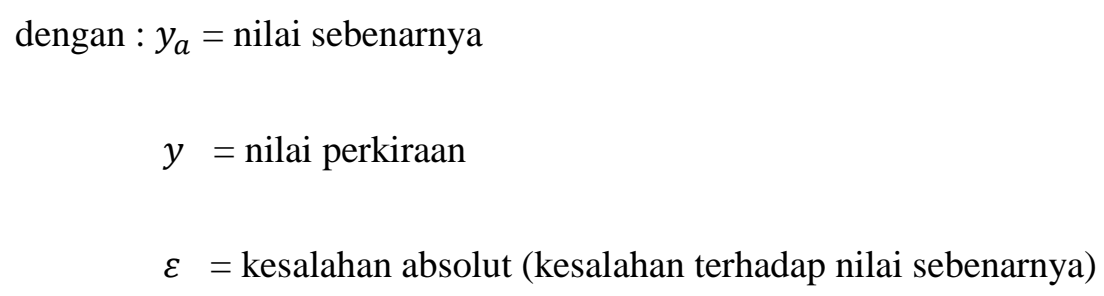

6. Menjelaskan tentang Metode Range Kutta.

7. Menyelesaikan masalah menggunakan Metode Range Kutta-3, dengan menggunakan persamaan umumnya:

$$
y_{i+1}=y_{i}+\left(\frac{1}{6} k_{1}+4 k_{2}+k_{3}\right) h
$$

Dimana:

$$
a=\text { parameter }
$$

$k$ adalah:

$$
k_{j}=f\left(x_{i}+h p_{j}, y_{i}+h \sum_{l=1}^{j-1} q_{j l} k_{l}\right)
$$

Dimana diperoleh

$$
\begin{gathered}
k_{1}=f\left(x_{i}, y_{i}\right) \\
k_{2}=f\left(x_{1}+p_{2} h, y_{i}+q_{21} k_{1} \cdot h\right) \\
k_{3}=f\left(x_{1}+p_{3} h, y_{i}+q_{31} k_{1}+q_{32} k_{2} \cdot h\right)
\end{gathered}
$$

\section{Hasil Dan Pembahasan}

Kasus-kasus yang dibahas adalah kasus-kasus yang sudah mempunyai solusi persamaan diferensial. Oleh karena itu berikut merupakan hasil dari proses perhitungan persamaan diferensial linier tingkat dua dengan menggunakan metode Runge-Kutta ordo-3. Untuk mempermudah penulis, untuk semua kasus pada pembahasan ini akan diselesaikan menggunakan alat bantu program matlab. Hasil perhitungan akan diperlihatkan dengan tabel dan grafik sesuai kasus yang akan diselesaikan.

\section{Kasus 1}

$$
y^{\prime \prime}-4 y^{\prime}+4 y=x+10
$$

Dengan nilai $x_{0}=0, y(0)=1$ dan $y^{\prime}(0)=2$ 
Hasil perhitungan dengan menggunakan program matlab untuk mencari solusi numerik dan solusi analitik dengan ukuran langkah $h=0.1$ diperlihatkan dengan grafik sebagai berikut.

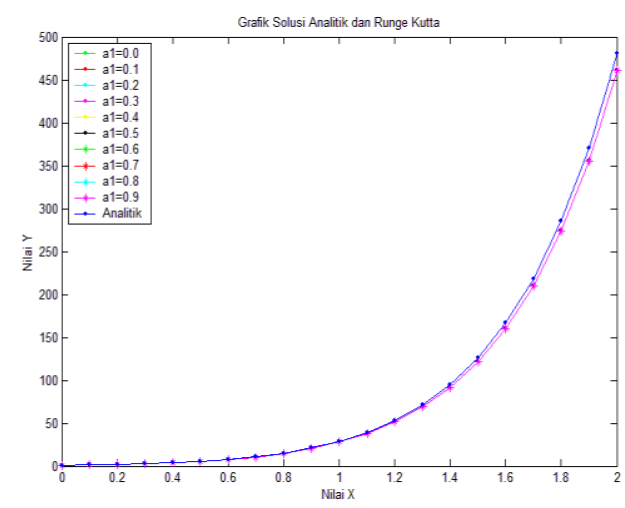

\section{Gambar1 Grafik Solusi Analitik dan Solusi Numerik Kasus 1 dengan nilai parameter $a_{1}$ yang berbeda}

Pada tabel sebelumnya, perhitungan menggunakan ukuran langkah $h=0.1$ dan menghasilkan nilai error yang cukup besar untuk metode Runge-Kutta. Oleh karena itu pada grafik dibawah dilakukan perhitungan dengan menggunakan ukuran langkah yang lebih kecil lagi yaitu $h=0.01$. Untuk lebih jelasnya dapat dilihat grafik berikut.

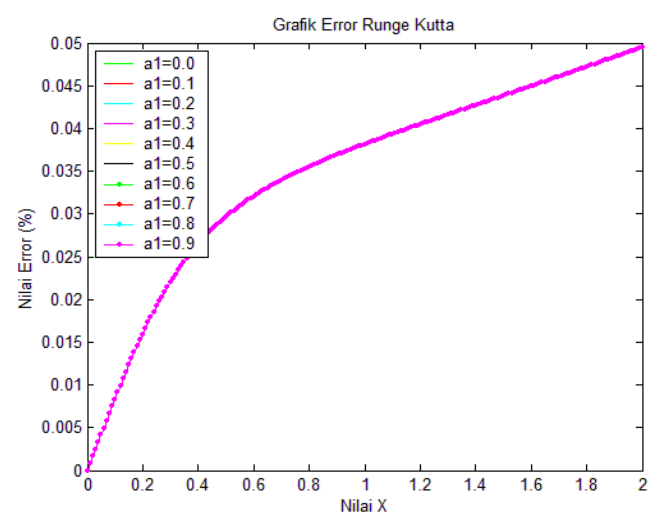

\section{Gambar 2 Grafik nilai error kasus 1 untuk setiap nilai parameter $a_{1}$}

Dari Gambar 2 nilai error yang dihasilkan lebih kecil dibandingkan dengan nilai error yang diperlihatkan data sebelumnya. Hal ini disebabkan karena pada Gambar 2 diberikan ukuran langkah yang lebih kecil dalam penyelesaiannya dibandingkan dengan penyelesaian. Semakin kecil ukuran langkah yang diberikan maka akan semakin kecil error yang diperoleh dalam arti solusi yang diperoleh akan semakin mendekati nilai sebenarnya. Pada Gambar 2 dapat dilihat bahwa nilai error untuk setiap nilai parameter $a_{1}$ tidak terlihat perbedaan. 
Kurva nilai error pada parameter $a_{1}=0$ sampai $a_{1}=0.8$ ditutupi oleh kurva nilai error parameter $a_{1}=0.9$

\section{Kasus 2}

$y^{\prime \prime}-5 y^{\prime}+6 y=x e^{3 x}$

Dengan nilai $x_{0}=0, y(0)=1$ dan $y^{\prime}(0)=1$

Hasil perhitungan dengan menggunakan program matlab untuk mencari solusi numerik dan solusi analitik dengan ukuran langkah $h=0.1$ diperlihatkan dengan grafik sebagai berikut.

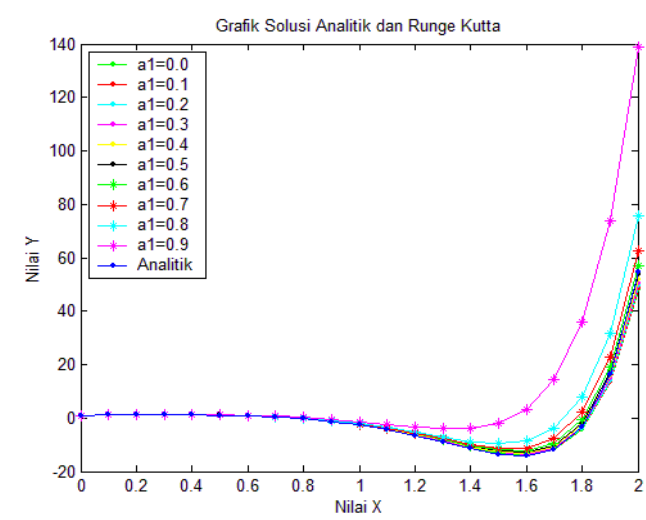

\section{Gambar 3 Grafik Solusi Analitik dan Solusi Numerik Kasus 2dengan nilai parameter $a_{1}$ yang Berbeda}

Pada grafik dibawah ini dilakukan perhitungan dengan menggunakan ukuran langkah yang lebih kecil lagi, yaitu $h=0.01$. Untuk lebih jelasnya dapat dilihat grafik berikut.

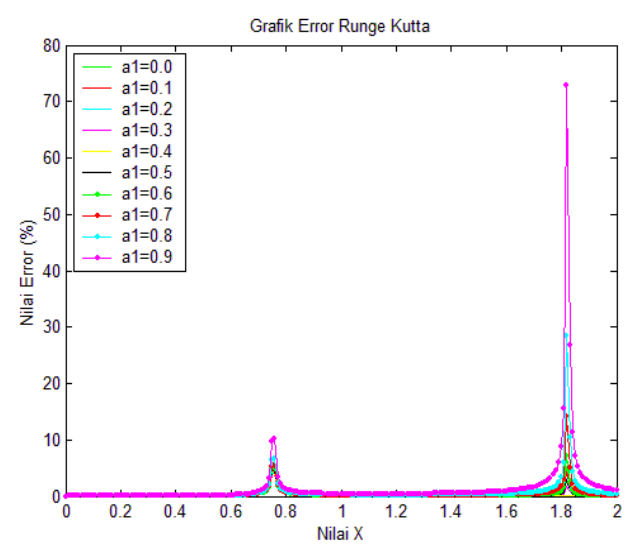

\section{Gambar 4 Grafik nilai error kasus 2 untuk setiap nilai parameter $\boldsymbol{a}_{1}$}

Nilai error terbesar berada pada parameter $a_{1}=0.9$ tepatnya di titik $x=1.82$ yaitu $\varepsilon=72.78536$. Nilai error pada interval tersebut terus meningkat dengan nilai yang tinggi sampai titik $x=1.82$ dan kembali menurun secara normal. Terjadinya nilai error yang cukup tinggi pada $x=1.82$ dipengaruhi oleh nilai koefisien dari fungsi polinomial 
berderajat satu pada $H(x)$. Semakin kecil nilai koefisien maka lonjakan nilai error pada kurva akan semakin runcing dan posisi lonjakan akan berpindah ke kiri sumbu $x$. Sedangkan apabila koefisien nilainya diperbesar maka bentuk kurva error akan semakin tumpul dan nilai error juga akan semakin kecil untuk semua parameter. Pemberian nilai awal $x, y$ dan $y^{\prime}$ yang tepat juga mempengaruhi bentuk kurva error pada kasus 2 .

\section{Kasus 3}

$y^{\prime \prime}-3 y^{\prime}-4 y=-8 e^{x} \cos 2 x$

Dengan nilai $x_{0}=0, y(0)=0$ dan $y^{\prime}(0)=1$

Hasil perhitungan solusi numerik dan solusi analitik dengan ukuran langkah $h=0.1$ diperlihatkan dengan grafik sebagai berikut.:

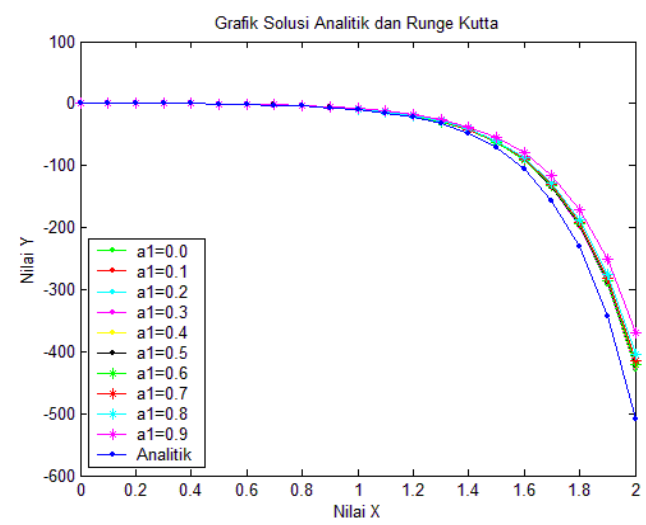

Gambar 5 Grafik Solusi Analitik dan Solusi Numerik Kasus 3dengannilai parameter $a_{1}$ yang berbeda

Pada grafik dibawah dilakukan perhitungan dengan menggunakan ukuran langkah yang lebih kecil, yaitu $h=0.01$. Untuk lebih jelasnya dapat dilihat grafik berikut.

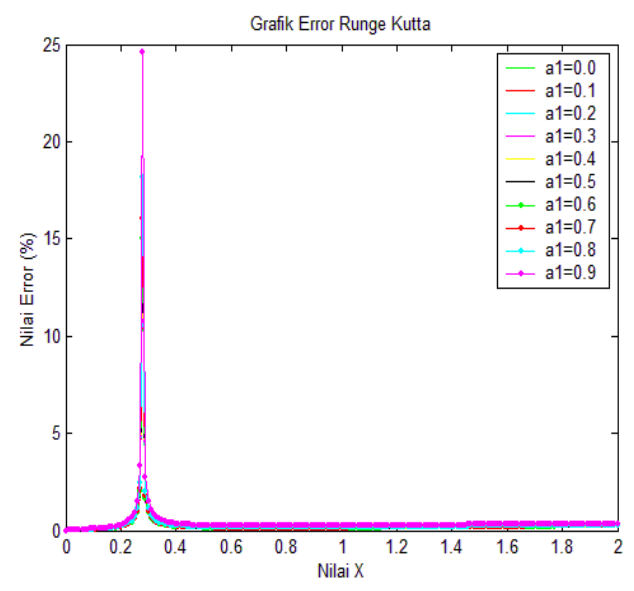

Gambar 6 Grafik nilai error kasus 3 untuk setiap nilai parameter $a_{1}$ 
Pada kasus 3 nilai error terbesar pada interval $0 \leq x \leq 2$ berada pada parameter $a_{1}=$ 0.9 yaitu pada titik $x=0.27$. Pada titik tersebut nilai error mencapai 24.63. Untuk parameter lain, nilai error pada titik $x=0.27$ juga mengalami kenaikan yang cukup tinggi dibandingkan denga nilai error pada nilai $x$ yang lain. Terjadinya nilai error yang sangat tinggi pada $x=0.27$ dipengaruhi oleh bentuk fungsi $H(x)$ dari suatu persamaan diferensial. Pada kasus 3 fungsi $H(x)$ merupakan kombinasi dari fungsi trigonometri dan fungsi eksponensial natural. Apabila koefisien dari fungsi eksponensial natural pada kasus 3 diperbesar maka kurva error akan semakin cembung dan apabila koefisiennya diperkecil maka kurva error akan semakin lancip atau runcing dan mengalami pergeseran arah kiri sumbu $x$.

\section{Analisis Error}

Menganalisis Error sangat penting di dalam perhitungan menggunakan metode numerik. Error berasosiasi dengan seberapa dekat solusi hampiran terhadap solusi sejatinya. Semakin kecil error-nya, semakin teliti solusi numerik yang didapatkan. Dalam menganalisa error, ada dua hal yang harus dipahami yaitu, bagaimana error timbul dan bagaimana menghitung error.

Misalkan yadalah hampiran (solusi numerik) terhadap nilai sejati $y_{a}$ (solusi analitik), maka selisih

$$
\varepsilon=y_{a}-y
$$

disebut error. Jika tanda Error (positif atau negatif) tidak dipertimbangkan, maka muncul istilah error mutlak yang didefinisikan sebagai

$$
|\varepsilon|=\left|y_{a}-y\right|
$$

Sayangnya, ukuran $\varepsilon$ kurang bermakna sebab tidak menceritakan seberapa besar error itu dibandingkan dengan solusi analitiknya. Oleh karena itu, error harus dinormalkan terhadap solusi analiti atau dalam persentase diperoleh

$$
\varepsilon_{r}=\frac{\varepsilon}{y_{a}} \times 100 \%
$$

Karena error dinormalkan terhadap nilai sejati (solusi analitik), maka error relatif tersebut dinamakan juga error relatif sejati. Pada pembahasan ini, penulis menjadikan error relatif berbentuk persentase. 
Pada bab ini akan dicari nilai nilai parameter yang memiliki error terkecil pada interval $0 \leq a_{1} \leq 0,9$. Karena $a_{1}$ adalah bilangan riil, maka ada banyak bilangan yang berada pada interval tersebut. Maka dari itu dibatasi nilai $a_{1}$ terkecil adalah $10^{-4}$. Untuk mencari nilai error terkecil pada interval tersebut maka dilakukan metode pencarian dengan algoritma berikut:

1. Definisikan ukuran langkah parameter, batas bawah dan atas. Kita misalkan ukuran langkah parameter adalah $l$, batas atas adalah $c$ dan batas bawah adalah $b$.

2. Uji nilai error apakah nilai error selalu mengalami kenaikan atau pertambahan dalam arti kurva nilai error menaik pada interval $b \leq a_{1}<c$.

a. Jika iya, maka nilai error terkecil berada pada parameter $a_{1}=b$ dan nilai error terbesar berada pada nilai parameter $a_{1}=c-10^{4}$. Proses iterasi dihentikan.

b. Jika tidak, lakukan langkah 2 .

3. Uji nilai error apakah nilai error selalu mengalami penuruan nilai atau dalam arti kurva nilai error turun pada interval $b \leq a_{1}<c$.

a. Jika iya, maka nilai error terkecil berada pada parameter $a_{1}=c-10^{4}$ dan nilai error terbesar berada pada nilai parameter $a_{1}=b$. Proses iterasi dihentikan.

b. Jika tidak lakukan langkah 3 .

4. Misalkan nilai terkecil adalam $m$. Jika nilai error pada parameter $a_{1}=0$ adalah $e_{1}$. Maka kita misalkan $m=e_{1}$. Bandingkan muntuk setiap parameter $a_{1}$. Apabila terdapat bilangan yang lebih kecil dari $m$ maka bilangan itu menjadi $m$. Jika sudah dapat bilangan terkecil pada setiap parameter maka langkah 4 .

5. Tentukan ukuran langkah yang baru dengan batas bawah $b=m-p$ dan batas atas $c=m+p$.

6. Tentukan ukuran langkah parameter yang baru dengan $p=p^{10^{1}}$.

7. Ulangi langkah 1 .

Berdasarkan pengamatan dari perhitungan, dan dengan menggunakan algoritma diatas maka diperoleh hasil sebagai berikut.

1. Pada kasus 1 , nilai error relatif terkecil pada $x=2$ berada pada $a_{1}=0.5$ yaitu . $\varepsilon_{r}=0.049449 \%$. Nilai error pada parameter yang lain tidak jauh berbeda dengan nilai error pada $a_{1}=0.5$. Pada gambar dapat dilihat bahwa perubahn nilai error untuk parameter yang berbeda hampir membentuk kurva datar, dalam arti memiliki 
perubahan nilai error yang sangat kecil. Apabila digunakan ukuran langkah $h=0.1$, nilai error untuk setiap parameter tidak ada perbedaan. Semua parameter memiliki nilai error yang sama. Adapun grafik kurva error relatif pada $x=2$ untuk setiap parameter $a_{1}$ adalah sebagai berikut

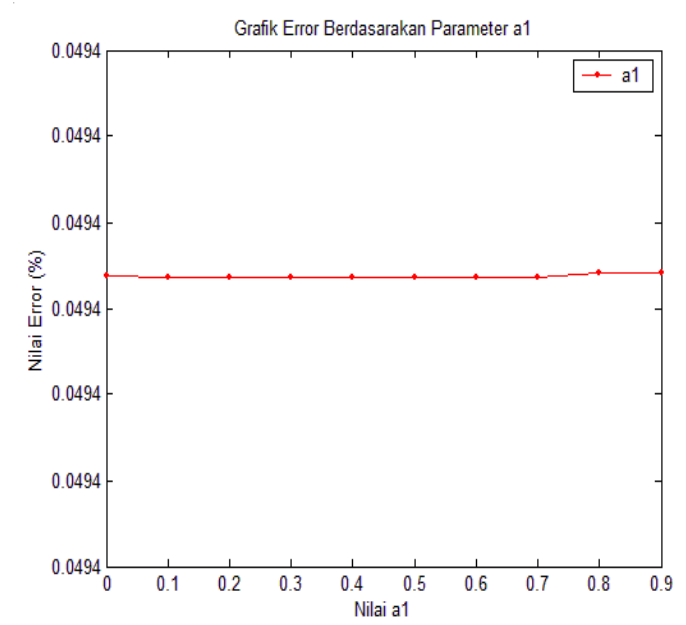

\section{Gambar 7 Grafik Eror Berdasarkan Nilai ParameterPada Kasus 1}

2. Berdasarkan algoritma pencarian nilai error terkecil maka pada kasus 2 diperoleh nilai error relatif terkecil pada $x=2$ berada pada $a_{1}=0.5661$ yaitu $\varepsilon_{r}=0 \%$, Karena bentuk kurva tidak kurva yang selalu menaik atau kurva yang selalu turun maka proses pencarian nilai error terkecil sampai pada iterasi yang terakhir yaitu iterasi ke4. Pada iterasi pertama yaitu pencarian nilai error terkecil pada interval $0 \leq a_{1}<$ 1dimana ukuran langkah parameter adalah 0.1. Dari hasil perhitungan diperoleh nilai error terkecil pada $a_{1}=0.6$. (lihat gambar 3.11a). Pada iterasi kedua yaitu pencari nilai error terkecil pada interval $0.5 \leq a_{1}<0.7$ dimana ukuran langkah parameter menjadi 0.01. Dari hasil perhitungan diperoleh nilai error terkecil pada $a_{1}=0.57$. (lihat gambar 3.11b). Pada iterasi ketiga yaitu pencarian nilai error terkecil pada interval $0.56 \leq a_{1}<0.58$ dimana ukuran langkah parameter menjadi 0.001. Dari hasil perhitungan diperoleh nilai error terkecil pada $a_{1}=0.566$. (lihat gambar 3.11c) Pada iterasi keempat yaitu pencarian nilai error terkecil pada interval $0.565 \leq a_{1}<$ 0.567dengan ukuran langkah menjadi 0.0001. Dari hasil perhitungan diperoleh nilai error terkecil pada $a_{1}=0.5661$ dengan nilai error yaitu $\varepsilon_{r}=0 \%$. (lihat gambar 4.11d). Untuk lebih jelasnya lihat gambar dibawah ini 


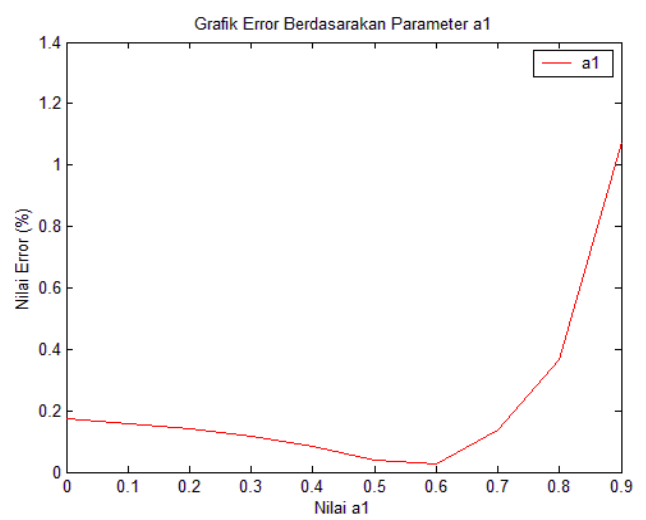

Gambar 8 Grafik Eror Berdasarkan Nilai Parameter Pada Kasus 2 (ukuran langkah $=0.1$ )

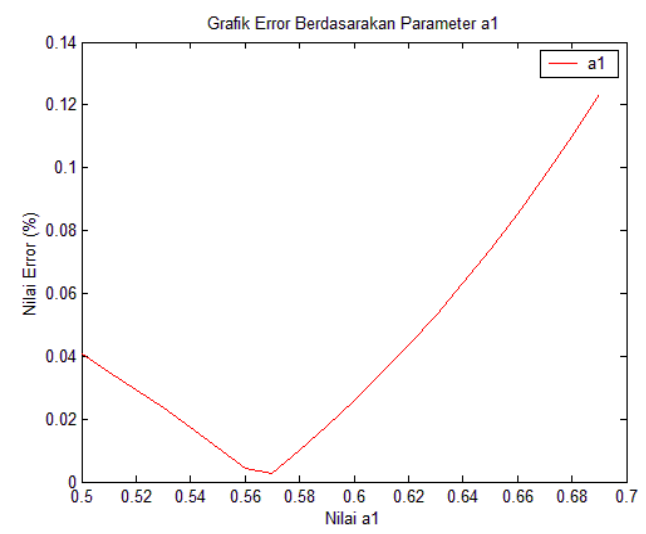

Gambar 9 Grafik Eror Berdasarkan Nilai Parameter Pada Kasus 2 (ukuran langkah $=0.01$ )

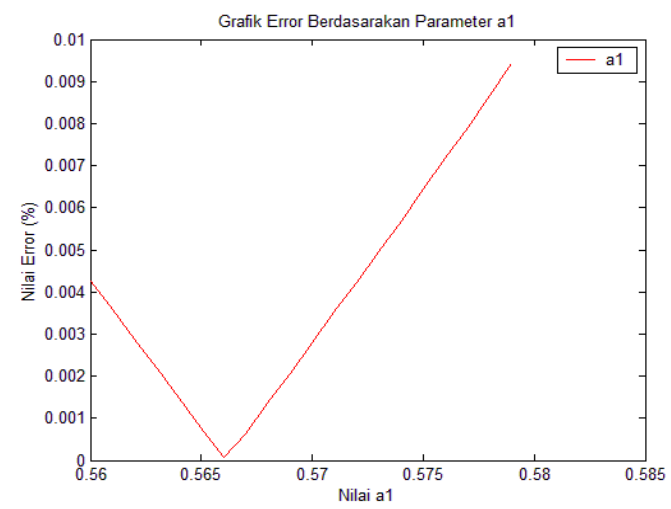

Gambar 10 Grafik Eror Berdasarkan Nilai Parameter Pada Kasus 2 (ukuran langkah $=0.001$ )

Pada Gambar 10 diperoleh error minimum berada pada $a_{1}=0.566$ dengan nilai error yaitu $\varepsilon_{r}=0.000071 \%$ 


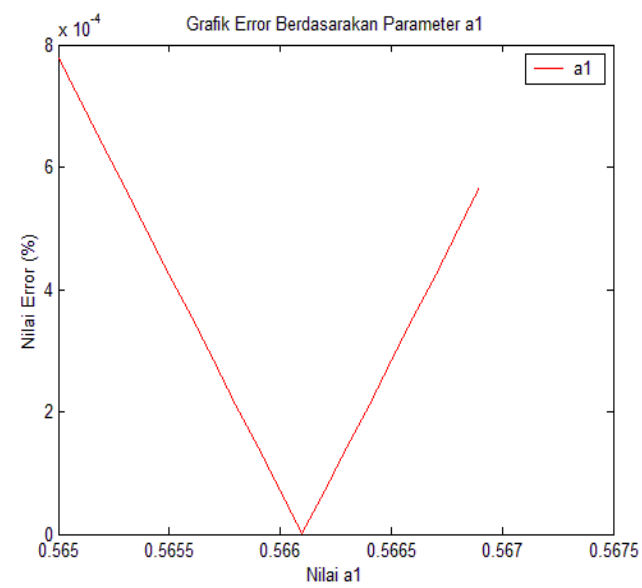

Gambar 11 Grafik Eror Berdasarkan Nilai Parameter Pada Kasus 2 (ukuran langkah $=0.0001$ )

Pada Gambar 11 diperoleh error minimum berada pada $a_{1}=0.5661$ dengan nilai error yaitu $\varepsilon_{r}=0 \%$

3. Pada kasus 3, nilai error relatif terkecil untuk $x=2$ diperoleh pada nilai parameter $a_{1}=0.0$, adapun persentase error relatif terkecil yaitu $\varepsilon_{r}=0.222685 \%$. Sedangkan error relatif terbesar berada pada nilai $a l=0.9$ yaitu dengan persentase $\varepsilon_{r}=$ $0.361192 \%$. Setiap nilai parameter $a_{1}$ memiliki perbedaan nilai error yang berbeda. Nilai error relatif terus meningkat mulai dari parameter $a_{1}=0.0$ sampai parameter $a_{1}=0.9$. Pada kasus 3 nilai parameter juga mempengaruhi besar kecilnya nilai error. Adapun grafik kurva error relatif pada $x=2$ untuk setiap parameter $a_{1}$ adalah sebagai berikut:

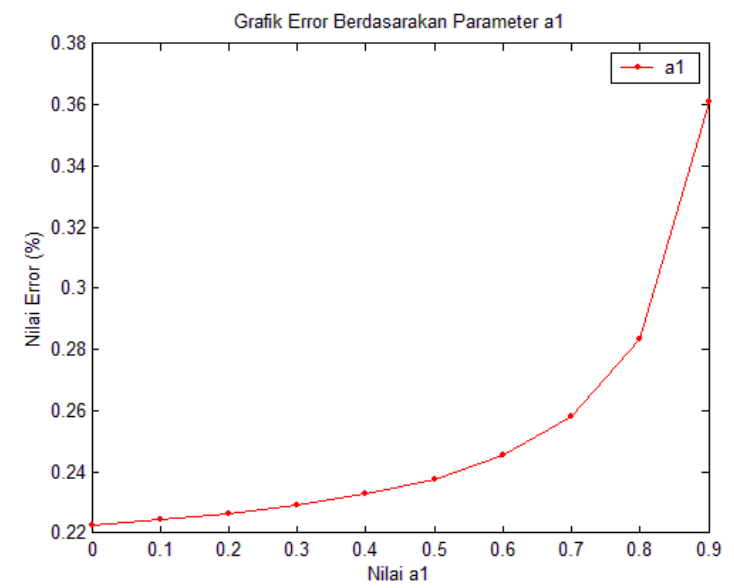

Gambar 12 Grafik Eror Berdasarkan Nilai Parameter Pada Kasus 


\section{Kesimpulan}

Dari penelitian yang telah dilakukan ini dapat diambil beberapa kesimpulan mengenai penyelesaian persamaan diferensial menggunakan metode Runge-Kutta Ordo3.

1. Penyelesaian persamaan diferensial linier tingkat dua menggunakan metode Runge-Kutta yaitu dengan menjadikan persamaan diferensial linier tingkat dua menjadi suatu sistem persamaan diferensial. Dimana didalam sistem tersebut terdapat dua buah persamaan yang memiliki saling keterkaitan, yaitu persamaan diferensial linier tingkat dua yang dirubah menjadi dua persamaan diferensial tingkat satu.

2. Pada pembahasan skripsi ini, tidak diperoleh nilai parameter yang tetap untuk mendapatkan nilai error yang paling minimum pada setiap penyelesaian persamaan diferensial linier tingkat dua secara umum. Setiap parameter memiliki nilai error yang bervariasi pada masing-masing persamaan.

3. Pada penyelesaian persamaan diferensial linier tingkat dua menggunakan metode Runge-Kutta diperoleh solusi yang beragam dan nilai error yang berbeda-beda pada satu kasus yang sama. Hal ini dikarenakan metode Runge-Kutta tidak memiliki solusi yang tunggal, terkecuali Metode Runge-Kutta ordo satu. Besar kecilnya nilai error pada metode Runge-Kutta dipengaruhi oleh pemilihan nilai parameter dan ukuran langkah yang diberikan. Semakin kecil ukuran langkah yang diberikan maka semakin kecil nilai error yang dihasilkan. Selain itu, penentuan nilai awal $x_{0}, y_{0}$ dan $y^{\prime}{ }_{0}$ juga mempengaruhi besar kecilnya nilai error.

\section{DAFTAR PUSTAKA}

[1] Birkhoff, G., and Rota, G.C. 1978. Ordinary Differential Equations, 3rd Edition. USA: John Wiley \&Sons, Inc.

[2] Marwan, dan Munzir, S. 2009. Persamaan Diferensial. Yogyakarta: Graha Ilmu.

[3] Nugroho, D.B. 2011. Persamaan Diferensial Biasa dan Aplikasinya. Yogyakarta: Graha Ilmu.

[4] Ralston, A. 1978. Runge-Kutta Methods with Minimum Error Bounds. New Jersey: Stevens Institute of Technology.

[5] Verner, J.H. 2010. Numerically Optimal Runge-Kutta Pairs with Interpolants. 
KARISMATIKA

p-ISSN : $2443-0366$

VOL. 3 NO. 2 AGUSTUS 2017

e-ISSN : 2528 -- 0279

[6] Gerald, CF., and Wheatley, P., 2004. Applied Numerikal Analysis. 7th Edition. USA: Pearson Education, Inc.

[7] Finizio, N., and Ladas, G. 1988. Persamaan Diferensial Biasa dengan Penerapan Modern. Edisi Kedua. Terjemahan Santoso, Widiarti. Jakarta : Erlangga. 